\title{
PENYEDIAAN SARANA DAN PRASANA PENDUKUNG POLA HIDUP BERSIH DAN SEHAT GUNA MEMUTUS MATA RANTAI PENULARAN COVID-19
}

\author{
Zulhelman $^{1 \otimes}$, Asri Wulandari², Dandun Widhiantoro ${ }^{3}$ \\ 1,2,,3 Politeknik Negeri Jakarta \\ Jl. Prof. Dr. G.A. Siwabessy Politeknik Negeri Jakarta, Kampus Baru UI Depok \\ $\otimes_{e-m a i l: 1 \text { zulhelman@elektro.pnj.ac.id }}$
}

\begin{abstract}
Habituation of Clean and Healthy Lifestyle to Break the Covid-19 Transmission Link is a community service activity conducted by the Multimedia Broadband Study Program of PNJ Department of Electrical Engineering. This activity is based on the fact that it is currently outbreak of the Covid 19 virus which is very rapidly spreading. One of the causes of the rapid spread is bad habits in our society that are not accustomed to getting used to clean and healthy lifestyles as required by the Ministry of Health of the Republic of Indonesia. As it is known, the covid-19 virus can enter and infect humans through the mouth, nose and eyes. The human limbs that often touch the part are the hands. Covid-19 spreads to people through droplets that sufferers emit when they speak, sneeze or cough. The droplet may be attached to objects that are often touched by the hand. Without washing, if the hand that accidentally touches the droplet is used to eat or touch parts of the mouth, nose and eyes, then it will most likely contract. Therefore, it is necessary to do a program of habituation of clean and healthy lifestyle including washing hands with soap. To support the program, this community service activity has been conducted training in the manufacture of hand wash soap, the provision of portable hand wash and hand soap and the distribution of masks.
\end{abstract}

Keywords_training, clean living, hand wash

\begin{abstract}
Abstrak
Pembiasaan Pola Hidup Bersih dan Sehat Guna Memutus Mata Rantai Penularan Covid-19 adalah sebuah kegiatan pengabdian kepada masyarakat yang dilaksanakan oleh Program Studi Broadband Multimedia Jurusan Teknik Elektro PNJ. Kegiatan ini dilandasi oleh kenyataan bahwa saat ini sedang mewabah virus Covid 19 yang sangat cepat penyebarannya. Salah satu penyebab cepatnya penyebaran adalah kebiasaan buruk di masyarakat kita yang belum terbiasa membiasakan Pola Hidup Bersih dan Sehat sebagaimana yang disyaratkan oleh Kementerian Kesehatan RI. Seperti diketahui, virus covid 19 dapat masuk dan menjangkiti manusia adalah melalui mulut, hidung dan mata. Anggota tubuh manusia yang sering menyentuh bagian tersebut adalah tangan. Covid 19 menyebar menjangkiti manusia melalui droplet yang dikeluarkan penderita ketika ia berbicara, bersin atau batuk. Droplet tersebut bisa saja menempel pada benda-benda yang sering disentuh oleh tangan. Tanpa mencuci, apabila tangan yang tidak sengaja menyentuh droplet tersebut digunakan untuk makan atau menyentuh bagian mulut, hidung dan mata, maka kemungkinan besar ia akan tertular. Oleh karena itu sangat perlu untuk dilakukan program pembiasaan pola hidup bersih dan sehat diantaranya adalah mencuci tangan dengan sabun. Untuk mendukung program tersebut maka pada kegiatan pengabdian kepada masyarakat kali ini telah dilakukan pelatihan pembuatan sabun cuci tangan, pemberian tempat cuci tangan portable beserta sabun cuci tangan serta pembagian masker.
\end{abstract}

Kata kunci-pelatihan, hidup bersih, cuci tangan

\section{Pendahuluan}

\section{Latar Belakang}

Pandemi Covid-19 yang melanda dunia termasuk Indonesia telah memaksa seluruh manusia di dunia untuk kembali menjalankan Pola Hidup Bersih dan Sehat (PHBS). Penularan Covid-19 yang paling cepat adalah melalui droplet penderita yang tersebar dan tersentuh oleh tangan manusia. Tangan yang telah menyentuh droplet tadi biasanya akan sangat mudah menularkan penyakit karena lupa atau tidak terbiasa mencuci tangan. Penularan Covid-19 ini lewat tangan yang kotor lalu menyentuh mulut atau hidung (Syakriah, 2020).

Perilaku hidup bersih sehat pada dasarnya merupakan sebuah upaya untuk menularkan pengalaman mengenai pola hidup sehat melalui individu, kelompok ataupun masyarakat luas dengan jalur jalur komunikasi sebagai media berbagi 
informasi. Ada berbagai informasi yang dapat dibagikan seperti materi edukasi guna menambah pengetahuan serta meningkatkan sikap dan perilaku terkait cara hidup yang bersih dan sehat (Jamilatun, 2019).

Tujuan utama dari gerakan PHBS adalah meningkatkan kualitas kesehatan melalui proses penyadartahuan yang menjadi awal dari kontribusi individu - individu dalam menjalani perilaku kehidupan sehari hari yang bersih dan sehat. Manfaat PHBS yang paling utama adalah terciptanya masyarakat yang sadar kesehatan dan memiliki bekal pengetahuan dan kesadaran untuk menjalani perilaku hidup yang menjaga kebersihan dan memenuhi standar kesehatan (Gani et al., 2015).

Depok adalah salah satu daerah zone merah penyebaran Covid-19 Kecamatan Beji menjadi kecamatan tertinggi di Depok dengan kasus Covid 19 dengan kasus konfirmasi positif 40, PDP 133, ODP 302, OTG 108 dan meninggal 1 orang. Kelurahan Beji sebagai salah satu kelurahan di Kecamatan Beji Kota Depok memiliki kasus covid 19 yang tinggi diantara kelurahan lain yakni konfirmasi positif 5, PDP 44, OPD 85, OTG 21 meninggal 1 (Depok, 2020). Perlunya program penggalakan Pola Hidup Bersih dan Sehat (PHBS) guna memutus mata rantai penularan covid 19 di Kelurahan Beji Khususnya di wilayah RW 014.

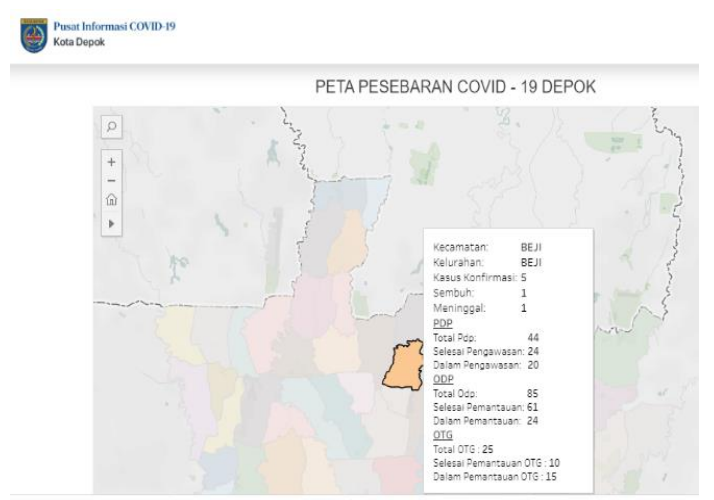

Gambar 1. Peta Sebaran Covid 19 di Kelurahan Beji Kota Depok(Depok, 2020)

\section{Tujuan Program}

Program pemberdayaan ini bertujuan agar masyarakat menjadi lebih terbiasa dalam Perilaku Hidup Bersih dan Sehat baik dimasa pandemi covid 19 maupun dimasa yang akan datang sehingga dapat menjadi kebiasaan baik dan mampu terhindar dari serangan berbagai macam penyakit yang diakibatkan oleh kuman/virus.

\section{Metode Pengabdian}

Kegiatan ini melibatkan berbagai pihak, antara lain dosen, teknisi dan mahasiswa Prodi D4-BM (Broadband Multimedia) Jurusan Teknik ElektroPNJ, pengurus, dan para ibu di wilayah RW 14 Beji. Politeknik Negeri Jakarta diwakili oleh prodi D4-BM berperan sebagai penyelenggara dalam rangka melaksanakan salah satu dari Tri Dharma Perguruan Tinggi, yaitu Pengabdian kepada Masyarakat. Kelurahan Beji khususnya RW 14 diwakili oleh pengurus dan Ketua RW 14 Beji, yang berlaku sebagai mitra, berperan menyediakan tempat dan tenaga.

Sarana dan prasarana yang akan digunakan dan telah tersedia di wilayah RW 014 Kelurahan Beji Kecamatan Beji Kota Depok adalah sarana pelatihan berupa balai RW untuk melaksanakan pengabdian Ipteks bagi Masyarakat. Penyediaan sarana cuci tangan serta peralatan pelatihan pembuatan sabun cuci tangan dan pelatih/trainernya telah disediakan dan diberikan oleh Program Studi Broadband Multimedia.Kegiatan ini dapat berkelanjutan mengingat pelatihan ini baru sebagai awal pembelajaran atau sebagai pengenalan.

Metode pengambilan data dan keputusan dalam pengabdian masyarakat ini dilakukan dengan berbagai cara, antara lain: koordinasi dengan Pengurus Wilayah setempat, survey kondisi Mitra, wawancara dan diskusi dengan Mitra tentang 
permasalahan utama yang dihadapi Mitra, diskusi dengan anggota Tim Pengusul tentang metode dan solusi penyelesaian permasalahan Mitra serta diskusi dengan Mitra tentang solusi yang ditawarkan oleh Tim Pengusul.

Metode dan alur pelaksanaan pengabdian masyarakat ini dapat dilihat sebagai berikut :

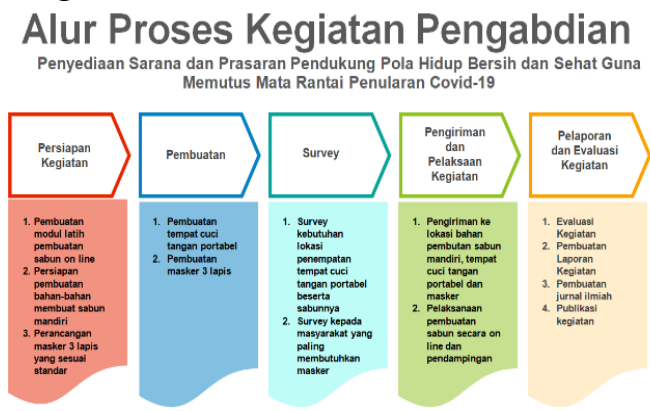

Gambar 2. Alur Proses Kegiatan Pengabdian

Kegiatan pengabdian masyarakat ini dibagi menjadi 5 tahap, dengan penjelasan sebagai berikut :

1. Persiapan Kegiatan; meliputi pembuatan modul latih pembuatan sabun, persiapan bahan-bahan pembuatan sabun mandiri, perancangan pembuatan tempat cuci portabel, perancangan pembuatan masker 3 lapis

2. Pembuatan, meliputi pembuatan tempat cuci tangan portabel, pembuatan masker 3 lapis

3. Survey, meliputi survey penempatan tempat cuci tangan dan masyarakat yang membutuhkan masker

4. Pengiriman dan pelaksanaan kegiatan, meliputi pengiriman ke lokasi bahan pembuatan sabun dan tempat cuci portable,pelaksanaan pelatihan pembuatan sabun dan pendampingan,

5. Pelaporan dan Evaluasi Kegiatan, meliputi evaluasi, pembuatan laporan, pembuatan jurnal dan publikasi.

\section{Hasil Dan Pembahasan}

Pelatihan Pembuatan Sabun Cair Cuci Tangan, Penyediaan Tempat Cuci
Tangan, dan Pembagian Masker merupakan kegiatan pengabdian pada masyarakat yang merupakan salah satu program tahunan dari Unit Penelitian dan Pengabdian pada Masyarakat (UP2M) Politeknik Negeri Jakarta. Program ini adalah sebagai salah satu kewajiban para dosen dalam menjalankan Tridharma perguruan tinggi selain dalam bidang pengajaran dan penelitian. Program bertujuan untuk memecahkan masalah yang timbul pada masyarakat secara komprehensif, bermakna, tuntas, dan berkelanjutan (suinable) dengan sasaran kelompok masyarakat yang bergerak dalam bidang usaha, sekolah, institusi pemerintah atau swasta atau masyarakat lainnya.

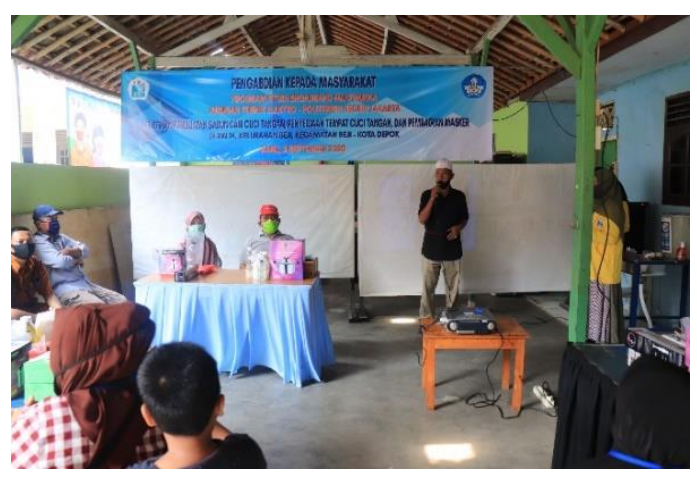

Gambar 3. Pembukaan Pelaksanaan Pengabdian Masyarakat

Pada masa pandemi Covid-19 ini program pengabdian kepada masyarakat di arahkan untuk membantu menangani masalah masyarakat untuk menghadapi pandemi saat ini. Daerah yang dipilih untuk dijadikan tempat pelatihan dari program studi Broadband Multimedia PNJ sebagai tempat untuk pelaksanaan Pengabdian Kepada Masyarakat setelah dilakukan survey adalah RW 14 Beji Kota Depok.

Pada Wilayah RW 14 Beji pada masa pandemik Covid-19, ternyata belum memiliki sarana tempat cuci tangan bagi warga sekitar atau tamu yang bekerjasama dengan karang tarunanya. Oleh karena itu dilakukan pembuatan dan penyerahan sarana tempat cuci untuk mendukung PHBS. 


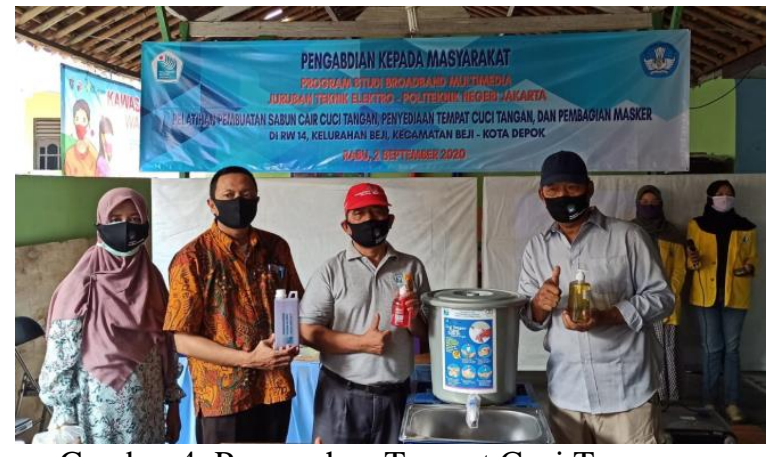

Gambar 4. Penyerahan Tempat Cuci Tangan

$$
\text { Portabel }
$$

Warga setempat juga diberi pelatihan pembuatan sabun cuci tangan guna mencegah penyebaran virus Covid19 dan diharapkan dapat menjadi sumber penghasilan bagi masyarakat setempat dengan berjualan sabun produksi sendiri. Hal ini dikarenakan, para warga sekitar ini kebanyakan berasal dari keluarga yang ekonominya kelas menengah dan kebawah.

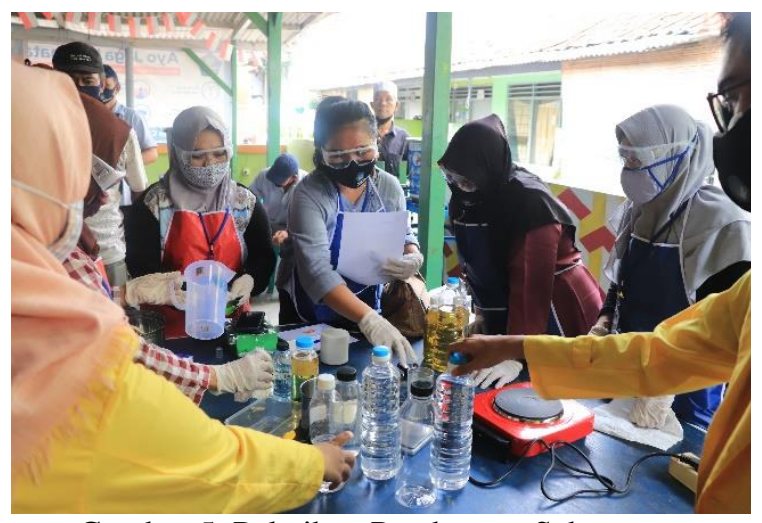

Gambar 5. Pelatihan Pembuatan Sabun

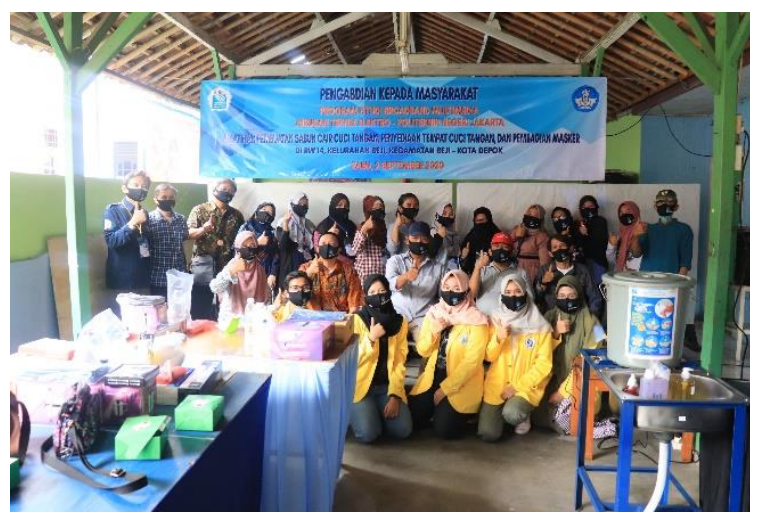

Gambar 6. Foto Bersama

Pelatihan berjalan dengan lancar dan baik, dimana dari pelaksanaan tersebut diharapkan warga sekitar dapat membuat sabun produksi sendiri sehingga dapat diperjual belikan untuk membantu ekonomi warga RW 14 Beji, dengan mematuhi protokol kesehatan Covid-19.Dengan demikian permasalahan ekonomi yang menjadi kendala dalam masa pandemik ini terbantu terpecahkan.

\section{Kesimpulan}

Kegiatan pengabdian kepada masyarakat prodi D4 Broadband Multimedia melibatkan dosen, PLP, mahasiswa, pengurus dan ibu-ibu Rumah tangga di wilayah RW14 Beji, Depok. Kegiatan ini menghasilkan luaran sebagai berikut:

1. Pelatihan pembuatan sabun secara off line di wilayah RW 14 Beji, Depok dan on line dalam bentuk video

2. Penyediaan sarana tempat cuci tangan umum beserta sabun cuci tangan (dengan proses pembuatan sabun yang dibuat sendiri)

3. Pembagian masker untuk memutus rantai penyebaran COVID 19

4. Menciptakan ekonomi kreatif untuk menambah penghasilan di masa pandemi dengan berjualan sabun produksi sendiri.

\section{Ucapan Terima Kasih}

Penulis mengucapkan terima kasih kepada UP2M Politeknik Negeri Jakarta yang telah memberi dukungan dana atas keberhasilan pengabdian ini.

\section{Daftar Pustaka}

[1] Abidah, Y. N., \& Huda, A. (2018). Pelaksanaan Program Perilaku Hidup Bersih dan Sehat ( PHBS ) di Sekolah Luar Biasa. 4(November), 87-93. 
[2] CDC. (2020). Use of Cloth Face Coverings to Help Slow the Spread of COVID-19. https://www.cdc.gov/coronavirus/2 019-ncov/prevent-getting-sick/diycloth-face-coverings.html

[3] Depok, G. T. P. P. C.-19 K. (2020). Portal data dan informasi terbaru mengenai COVID-19 di Kota Depok. https://ccc-19.depok.go.id/

[4] Gani, H. A., Istiaji, E., Pratiwi, P. E., Kesehatan, B. P., Perilaku, I., \& Kesehatan, F. (2015). PERILAKU HIDUP BERSIH DAN SEHAT (PHBS) PADA TATANAN RUMAH TANGGA MASYARAKAT USING (Studi Kualitatif di Desa Kemiren, Kecamatan Glagah, Kabupaten Banyuwangi) A Qualitative Study in Kemiren Village, Glagah Sub District, Banyuwangi Regency. Jurnal IKESMA, 11(1), 26-35.

[5] Jamilatun, M. (2019). Penyuluhan Mencuci Tangan sebagai Upaya Mencegah Kecacingan di Panti Asuhan Assomadiyyah Tangerang.
Jurnal Pengabdian Pada Masyarakat, 4(3), 273-278. https://doi.org/10.30653/002.20194 3.154

[6] Pittet, D. (2009). Hand Hygiene in Health Care First Global Patient Safety Challenge Clean Care is Safer Care. World Health, 30(1), 270.

https://doi.org/10.1086/600379

[7] Reed, C. (2020). No Title. Unesco. https://en.unesco.org/news/howsoap-kills-covid-19-hands

[8] Syakriah, A. (2020). Hand washing to counter COVID-19 still a luxury for Indonesia's urban poor. The Jakarta Post. https://www.thejakartapost.com/ne ws/2020/03/24/hand-washing-tocounter-covid-19-still-a-luxuryfor-indonesias-urban-poor.html

[8] Wahyudin, U., \& Setiaman, A. (2019). The characteristics and role of kyai in socializing health and clean behavior (phbs) in islamic boarding school. 3(2), 122-131. 